\title{
CONSTITUTIONAL REFORM IN SERBIA IN THE PERSPECTIVE OF EU MEMBERSHIP: EUROPEANIZATION OF SERBIAN CONSTITUTIONAL LAW
}

\author{
Andrej Stefanovic \\ University of Belgrade
}

\begin{abstract}
ते This paper deals with the process of constitutional reform in Serbia in the context of European integration. Serbia has officially started the negotiations process for European Union membership, something which will require Serbia to conduct fundamental changes to its legal, economic and political system. Changes will also have to be introduced to Serbia's Constitution. These changes, ultimately, will lead to the Europeanization of Serbian constitutional law and should enable this country's smooth and transparent transition towards membership in the Union.
\end{abstract}

Keywords: Europeanization; European Integration; Constitution; Constitutional Reform; European Union; Serbia; Enlargement

\section{Introduction}

The prospect of membership in the European Union has a powerful transformative effect, as it invites positive democratic, political, economic and societal changes to be brought. ${ }^{1}$ These changes entail the alignment of the acceding country's legal, economic and political system with the framework of the European Union and its legal system. This process has come to be known as Europeanization, and has gained in significance as countries that were formerly ruled by autocrats started their path of European integration. Europeanization of law, i.e. the changing of the country's legal system in the perspective of accession to the EU, is a consequence of the influence of European integration on the domestic legal systems of countries aspiring to EU membership. The constitution is by no means free from this influence, which is why we can talk about the Europeanization of a country's constitution and its constitutional law (Vorpsi, 2016, pp. 166-167).These changes emerge from the fact that the

1) Communication from the Commission to the European Parliament, the Council, the European Economic and Social Committee and the Committee of the Region. EU Enlargement Strategy. Brussels, 10.11.2015, p. 2. 
EU is no ordinary international organization- rather it is a supranational sui generis entity, based on a set of rules embedded in its Founding Treaties, which are considered a 'constitutional charter' (Les Verts, Case 294/83, [1986] E.C.R.). The EU legal system is therefore considered an autonomous, independent legal order, often leading to the Union being characterized as a quasi-federal construction (Borchard, 2010, pp. 31-32).

Serbia has gone a long way from being the only Western Balkan (WB) country that was denied European perspective and the status of a potential candidate country, to having opened the negotiations with the EU and seeking to fulfill all of the obligations stemming from the accession process by the year of 2020 . It has been noted, both in international ${ }^{2}$ and domestic $^{3}$ publications, that Serbia would not be able to enter the Union with this kind of a constitutional framework. This is why Serbia has already pledged to conduct changes in some parts of the Constitution, in order to meet the criteria of rule of law and sustainability of democratic institutions. On the other hand, there are also other constitutional deficiencies that need to be addressed, if Serbia is to secure for itself a smooth and legal transition towards EU membership. ${ }^{4}$

\section{Serbia's European Integration Path}

Before becoming an independent state, Serbia was part of the Socialist Federative Republic of Yugoslavia (SFRY). During the Cold War, the communist bloc in Eastern Europe, as a response to the formation of the European Economic Community (EEC), established its very own organization for economic cooperation, named the Council for Mutual Economic Assistance. Nevertheless, Yugoslavia did not participate within this structure, since it had a more independent and neutral foreign policy 2) European Commission for Democracy through Law (Venice Commission).Opinion
on the Constitution of Serbia.March 2007.

3) Antonijević, M. et al (2013).Ustav Republike Srbije-sedam godina pravne neizvesnosti i pet prioriteta za promenu.Beograd: YUCOM (Lawyers' Committee for Human Rights). 4) There is an intense discussion developing on whether Serbia will have to leave out the reference to Kosovo from the Preamble of its Constitution, where it is stated that Kosovo is an autonomous region within Serbia. It has been pointed to the fact that the 'erasing' of Kosovo from the Preamble is a demand that stems out of the process of comprehensive normalization Belgrade is conducting with Pristina, situated within Chapter 35 of the accession negotiations. However, this issues, although widely significant, not only for Serbia's internal affairs, but also for the international community as a whole, will not be analyzed in this paper, but only those changes that will affect Serbia's constitutional system and its constitutional law. 
orientation, than the other countries of the Eastern bloc. Therefore, it had an opportunity to cooperate with the West as well, something which Yugoslavia took advantage off in 1967, when it established diplomatic and political ties with the EECas the two partiessigned the Declaration on Mutual Relations. The relations were upgraded in the early 1970 s with the signing of two trade agreements which granted Yugoslavia multiple trade concessions, as well as preferential treatment on the EEC market. These relations reached their peak in 1980 with the signing of the Cooperation Agreement, which regulated not only trade and economic cooperation, but covered such issues as agriculture, traffic, science and research, etc. The further advancement of relations came in 1990 as the EEC pledged to support Yugoslavia in the restructuring of its banking and finance control system. However, with the outbreak of war in Yugoslavia, the Cooperation Agreement was suspended and the EEC, which would in this period become the European Union (EU), joined in the United Nations Security Council sanctions against Serbia (Miščević, 2009, pp. 171-175).

With the dissolution of the SFRY, Serbia and Montenegro formed a new federation- the Federal Republic of Yugoslavia (FRY). However, since the country was up until 2000 ruled by Slobodan Milosevic, there was no real possibility of reviving the relationship with the EU. On the other hand, due to conflicts on the territory of ex-Yugoslavia, the European Commission decided to envisage a new type of enlargement strategy towards this region (named the Western Balkans at this point). Having in mind the complexity of the situation in the $\mathrm{WB}$, the Commission proposed a new type of a relationship within the countries of this region- the Stabilization and Association Process (SAP)- and confirmed the status of potential candidate countries to all WB states, with the exception of Yugoslavia. After the democratic revolution of 2000, Yugoslavia was admitted to the WB group and its European perspective was confirmed by the Commission (Crnić, 2016, pp. 12-13).

Problems were evident that the federal ties between Serbia and Montenegro were in trouble and that the very existence of the federation was under question. The EU stepped in, in the form of Javier Solana, then the High Representative of the Union for Foreign Policy, and the decision was taken to reprogramme the country into a state union, where it would be allowed to conduct a referendum of independence after three years have expired. That is exactly what happened, and in May 2006 Montenegro declared its independence after a successful referendum. Serbia nevertheless continued with the SAP, and in April 2008 signed the 
Stabilization and Association Agreement (SAA) with the EU. New trouble followed, as the ratification process was severely prolonged, sincesome member states of the EU had considerations, mostly bilateral in nature, which induced them into not ratifying the SAA with Serbia. Despite this, Serbia decided to unilaterally implement the obligations stemming from the SAA. Finally, the SAA came into force in September 2013after Lithuania's ratification of the document (Crnić, 2016, pp. 18-19).

Montenegro's independence was also a trigger for Serbia to adopt a new Constitution. Even though it was expected that constitutional reforms are going to be performed as early as 2000, i.e. with the fall of the Milosevic dictatorship, nevertheless these changes were postponed all the way until 2006. Many politicians even stated that the constitutional order inherited from the past does not prevent the new democratic government from functioning (Antonijević, 2013, p. 12). Nevertheless, Montenegro's exit from the state union meant that the Constitutional Charter was not in effect anymore, and Serbia needed to regulate within a new constitution all of the areas previously regulated by the Constitutional Charter. This is why the government opted for the drafting process to be swift and quick, and the Constitution was drafted in a matter of weeks. However, this meant that the public was largely unaware of what was happening behind closed doors and could not express its approval or dissatisfaction with the proposed constitutional reform. After a successful referendum, the Constitution was proclaimed on the $8^{\text {th }}$ November 2006.

With the slowdown in the association process, Serbia turned to making further steps in the accession process. Following the application for membership made in 2009, the European Council granted Serbia the status of candidate country in March 2012 and decided to open the accession negotiations in June 2013, while the negotiations were formally opened in January 2014 when the first Intergovernmental Conference was held. ${ }^{5}$ Thus far, four negotiating Chapters have been opened, among which three are crucial: Chapters 23- which deals with judicial reform and human rights, 24- encompassing policies that fall within the Area of Justice, Freedom and Security- and 35- normally reserved for 'other issues', but in Serbia's case refers to the normalization of the relations between Belgrade and Pristina.

5) European Commission, Serbia Progress Report, 2014, p. 3-4. 


\section{The Reform of the Judiciary and the Prosecution}

The European Commission's enlargement strategy towards WB was changed in 2012, so that the enlargement policy was re-shifted towards core issues such as rule of law, fundamental rights, strengthening democratic institutions, including public administration reform. The new approach was coined 'fundamentals first', and emerged as a need of ensuring that acceding countries are fully transformed in accordance with these core values of the EU, before they actually become full-fledged members. ${ }^{6}$ The new approach was a consequence of the experiences the Commission acquired with past waves of enlargement which involved Central and Eastern European countries, some of which went through severe crises with regard to the stability of their democratic institutions. Thus, on a more practical level, WB countries are faced with a new structure of the enlargement process. Namely, Chapters 23 and 24, which cover core issues of rule of law, human rights and security, will be opened at the very beginning of the negotiations, and will be closed only at the very end of the process. Moreover, the Commission has introduced a mechanism, called the 'disequilibrium clause', which allows the Commission to suspend the entire negotiations process if the country does not fulfill obligations stemming from Chapters 23 and 24 (Petrović, Stojanović, Turkalj, 2015, p. 18).

The rule of law principle represents one of the key values enshrined in the EU Treaties (Article 2 of the TEU). With the reforms brought to the enlargement strategy, it is nowadays found at the heart of the accession process. Since the rule of law principle remains very broad, covering a whole range of issues, it needs to be narrowed down and operationalized in order to make it possible to assess the progress WB countries achieve in the accession process. Since most of these countries experienced significant problems with their judicial systems, which are not fully independent, but a target of political and criminal influence, strengthening the rule of law is particularly important in terms of improving the functioning and independence of the judiciary. EU primary law itself envisages the value of an independent and impartial judiciary, since the rights to fair trial is stipulated in Article 47 of the Charter of Fundamental Rights of the EU, a document which has the

6) Communication from the Commission to the European Parliament, the Council, the European Economic and Social Committee and the Committee of the Region, $E U$ Enlargement Strategy, Brussels, 10.11.2015, p. 5-6. 
same legal standing as the Founding Treaties. Progress in the field of creating an independent an impartial judiciary in the WB countries is not going to be made without strong political will that will lead to tangible results. ${ }^{7}$ In a broader sense, this means that there ought to be commitment to eliminating external influence over the judiciary and to devote adequate financial resources and training. Legal guarantees need to be put into place for fair trials. ${ }^{8}$

In Serbia's case, the independence of the judiciary is guaranteed by the Constitution, foremost by Article 4 which provides for the separation of powers. Serbia's version of the right to a fair trial can be found in Article 32 of the Constitution, which declared the right for every person to a public hearing before an independent and impartial tribunal. Also, Article 152 proscribes judges from entering politics. Functional immunity for judges is guaranteed by Article 151. Nevertheless, the Constitution does allow political influence: the National Assembly not only elects the President of the Supreme Court of Cassation and presidents of all other courts in the country, but it also elects to the post of a judge those persons who are elected to this position for the first time. All of this is done on the basis of proposals made by the High Judicial Council (HJC). Even though envisaged as an independent body, the HJC's composition and the election of its members reflects strong political interference, and the $\mathrm{HJCh}$ has failed to react publicly in protection of judicial independence in cases of political interference in the work of judges. ${ }^{9}$ The composition of the HJC is, de facto, entirely determined by the National Assembly: it elects 8 out of 11 members of the HJC, while the other 3 members-who are members ex officio- are also tied to the National Assembly: two of them also elected by the National Assembly (the President of the Supreme Court and the Minister of Justice) and one is a member of the National Assembly, in charge of the committee competent for judicial matters. Severe political interference is even more visible when it comes to public prosecutors: the National Assembly elects all prosecutors of all levels, including the State Prosecutor, even though the Constitution stipulates that the Prosecution is an independent state

7) Communication from the Commission to the European Parliament, the Council, the European Economic and Social Committee and the Committee of the Region, EU Enlargement Strategy, Brussels, 10.11.2015, p. 5.

8) European Commission. Screening Report Serbia: Chapter 24- Justice, Freedom and Security.

9) European Commission. Country Report for Serbia 2015, p. 12. 
body (Article 156), and that all public prosecutors enjoy functional immunity (Article 162). Thus, the State Prosecutorial Council (SPC), which gathers all prosecutors from the country, is entirely made up of officials directly elected by the National Assembly.

Gaps that exist in the independence of the judiciary are to be addressed through the proper amending of the Constitution and, subsequently, trough adapting the current legal framework with new constitutional provisions. ${ }^{10}$ In order to remedy the situation and to respond to all of the deficiencies the EU had identified, Serbia in its Action Plan for Chapter 23 has declared its readiness to amend the Constitution in those parts that are with concern to the independence of the judiciary and the prosecution. These changes ought to be made on the basis of analysis of European best practices, as well as a response to the criticism of the Venice Commission with regard to the 2006 Serbian Constitution. This task is to be given to a special working group for judicial reform. The final result, i.e. the adoption of the constitutional changes, is to be done in the last quarter of 2017, after which a new constitutional law (i.e. a constitutional act that implements new constitutional provisions) should be put in place. ${ }^{11}$

Both Serbia and the European Commission acknowledge that constitutional changes will not automatically lead to an independent judiciary and prosecution, but that changes need to take place in the legislative framework, as well as in granting greater financial autonomy to the HJC and the SPC, in order for them to conduct their affairs in an independent manner. However, constitutional changes represent the backbone of this process, without which there would be no sufficient and sustainable guarantee that there is separation of powers and the prohibition of interference of the legislative and the executive in judicial affairs.

\section{Establishing the Constitutional Basis for Membership}

One of the most urgent constitutional changes that are needed, when the accession to the $\mathrm{EU}$ is in sight, is the introduction of the integrative clause', i.e. a constitutional provision which would set forth the possibility of transferring constitutional powers to the EU. Even though the EU was created as an international organization, through the years it has moved a lot from this point, and has created structures that are unprecedented in international institutional law. It has acquired competences in various

10) European Commission, Country Report Serbia 2015, p. 50.

11) Ministry of Justice of Serbia.Action Plan for Chapter 23, p. 30-31. 
fields, all of which came about through member states transferring their powers to EU institutions. The Treaty on the Functioning of the European Union (TFEU) groups these competences (Article 3-6) from those where the EU has exclusive competence, through those competences that are shared between the EU and member states, all the way to those areas where the EU conducts the coordination of state policies, and, ultimately, areas where the EU offers support and supplement actions of member states. A broad spectrum of powers which the EU enjoys entails that states pursuing a membership within this organization ought to have in place legal instrument which would govern the transfer of powers. Furthermore, as the competences of the EU increased over the decades, it seemed important to broaden the constitutional basis for the transfer of sovereign powers for those member states that already had an integrative clause.' An example is Germany, which, until the creation of the EU in 1993, based its participation in European integration on Article 24 of the Basic Law. Unlike Article 24, which south to legalize the internationalization of federal sovereign powers of Germany, as a consequence of the antinationalistic approach of the post-War era, the new Article 23 adopts the 'open statehood' approach for Europeanizing national policy fields through the transfer of competences to the EU (Arnold, 2016, pp. 1-2).

The absence of such an 'integrative clause' is evident in the Serbian Constitution, and it was noticed first of all by the Venice Commission. Nonetheless, the Venice Commission Opinion on the Serbian Constitution acknowledges that Article 97 of the Constitution could act as a possible legal basis, if an 'integrative clause' was not introduced by the accession date. ${ }^{12}$ Article 97 (1) regulates the fields of competence of the Republic and it outlines that "The Republic of Serbia shall organize and provide for: sovereignty, independence, territorial integrity and security of the Republic of Serbia, its international status and relations with other countries and international organisations". However, it would be a leap of faith to consider this provision sufficient in establishing a legal mechanism for the transfer of sovereign powers. In order to justify this argument, one can take the example of Croatia, which changed its Constitution precisely for this reason: to introduce an integrative clause. The Croatian Constitution beforehand contained a provision that allowed Croatia to enter with other countries into associations and alliances (Article 135). Despite this, it was realized that a new provision

12) European Commission for Democracy through Law (Venice Commission). Opinion on the Constitution of Serbia. March 2007, p. 7. 
should be introduced which would explicitly refer to the transfer of sovereign powers to the $\mathrm{EU}$, as well as to regulate rights and obligations that stem out of the membership status (Article 141a). Therefore, the absence of such a provision would possibly endanger Serbia's accession to the EU, since it would put into question the constitutionality of such a move, indeed because the membership in the EU cannot be equaled to membership in 'classic' international organisations.

If the issue of the 'integrative clause' is resolved, the focus moves on to the problem of relationship between the two legal systems- the European and the Serbian one. Basis for this kind of a regulation can be found in Articles 16 and 194 of the Constitution. By analyzing Article 16 it can be concluded that Serbia opts for a monist approach towards international law, considering that this provision envisages direct effect of international agreements. If this recognition of direct effect could be extended from international agreements to legislative acts of EU institutions as well, there would be no problem with accepting one of the fundamental principles of EU law- direct effect. As always, the devil is in the detail. Unlike Article 16, Article 194 does not mention that international agreements have direct effect- rather it only states that they represent a part of the Serbian legal order. Problems which emerge through simultaneously reading the two articles is something that the Venice Commission refers to in its Opinion on the Serbian Constitution. Such inconsistencies could prove problematic for proper interpretation. ${ }^{13}$

With the accession to the EU, not only the status of the country, but also the status of individual citizens will be affected. Namely, citizens of an acceding country will become citizens of the EU and will be afforded rights that stem from such a status. European citizenship is given to every individual who has the nationality of a member state. However, European citizenship is additional and does not replace national citizenship. Therefore, member states are still in charge of defining conditions for acquiring and loss of citizenship. However, constitutional significance of European citizenship has been emphasized by the ECJ in cases such as Rottmann, Case C-135/08,[2008], where it stipulated that the conditions laid down by member states should not affect the rights conferred to citizens through EU law, and that cases referring to these issues can be subject to judicial review in light of general principles of the European legal order.

13) European Commission for Democracy through Law (Venice Commission). Opinion on the Constitution of Serbia. March 2007, p.7. 
The need for introducing special constitutional provisions for regulating rights of European citizens was recognized in the process of Croatia's accession to the EU, and a new article was introduced to the Croatian Constitution, which enumerates basic rights European citizens enjoy (Article 146). The Croatian solution in addressing this issue might be a good path for how Serbia should handle it: on the one hand, granting Serbian citizens'rights and freedoms stemming from EU law, and, on the other hand, guaranteeing other European citizens the same rights and freedoms on its territory.

\section{Issues for Further Debate: Supremacy of European Union Law}

Apart from the direct effect principle, EU law, according to the jurisprudence of the European Court of Justice (ECJ), is supreme in its interactions with national legal systems. This principle was inaugurated in a famous judgment in the Costa $v$ ENEL case, and was further elaborated in Internationale Handelsgesselschaft, Simmenthal and other cases. In the Costa judgment, Case 6-64, [1964], E.C.R, the ECJ solved the issue of hierarchy of norms between the Union order and the national legal orders. Supremacy of Union law was founded upon the importance of its uniform application in national legal systems, as well as the fulfillment of the necessity to combat potential infringement upon the authority of this supranational order (Čavoški, 2013, p. 88). Afterwards, the ECJ went beyond what it conceptualized in Costa, ruling in Internationale Handelsgesselschaft, Case 11-70, [1970], E.C.R,that EU law takes precedence over the national law as a whole, including constitutional law. However, in taking the endeavor of introducing the concept of supremacy, the ECJ was faced with the task of determining the faith of national norms that contradict and conflict the Union legal order. The answer was found in the Simmenthal, Case 106-77, [1978], E.C.R, case, where the ECJ said that the principle of supremacy renders all conflicting national law inapplicable and precludes the valid adoption of new legislative measures which would be contradicting to Union law.

The Serbian Constitution, apart from adopting a monist perspective towards the relationship between international and municipal law, also accepts the notion of supremacy of international agreements over national legislation. This relationship stems from Article 194 which envisages that laws and other general legal acts must be in conformity not only with the Constitution, but also with international agreements. However, 
international agreements are of lower legal value than the Constitution and must be in conformity with it, whereas the Constitutional Court is charged with ruling on the constitutionality of treaties- something which has been criticized as a possible trigger for international accountability of Serbia, since the Constitutional Court can assess the constitutionality of treaties only after they have been signed and ratified. ${ }^{14}$ Moreover, when this constitutional solution is put side by side with EU law, other problems can be detected as well. This kind of authority of the Constitutional Court allows for the possibility for it to adjudicate the cases on constitutionality of EU Founding Treaties, as well as to interpret them. This is a clear breach of primary EU law, since the ECJ is the only institution afforded with the task of interpreting and assessing the validity of EU law, and even it cannot pass judgments on the validity of primary EU law, but can only interpret it. Even though it does happen from time to time that national constitutional and supreme courts take on cases where they interpret EU law and even impose restrictions on its effect, nevertheless these kind of situations, for the sake of legal certainty, should be dismissed as soon as possible. It should start with abolishing the ex post assessment of constitutionality of international agreements, which would be replaced with ex ante constitutional review.

Since Articles 16 and 194 of the Constitution lay the basis for creating a supra-legal effect of international agreements, and, therefore, the EU law itself, the question remains should future constitutional changes go the next step and acknowledge the supremacy of EU law over the whole of Serbian law. Supremacy of EU law has been formulated and developed in the case law of the ECJ, and, so far, it has not been codified in primary EU law (with the exception of the failed Constitutional Treaty which did contain a provision which stipulated the supremacy of EU law). Therefore, there are no specific requirements on this issue for acceding countries. Due to this, member states range from those which jealously still cling to the traditional concept of national and state sovereignty (e.g. Poland), through those member states that have positioned themselves somewhere along the concept of constitutional pluralism, which entails the acceptance of a special status for EU law, all the way to member states which have constitutionally subordinated their legal system to EU law, through welcoming the full effect of the principle of supremacy of EU law (Chalmers, Davies, Monti, 2009, pp. 190-197).

14) European Commission for Democracy through Law (Venice Commission). Opinion on the Constitution of Serbia. March 2007, p. 6. 
Further debate should be conducted on these issues. Of course, Serbia does not face any hard conditioning as far as supremacy of EU law is concerned. There are no obstacles even ifSerbia decides to keep the current constitutional solution, or even if it decides to take the path of adopting a dualist approach towards the relationship between international and municipal law. However, this could lead to dangers of conflicts between the two legal systems and would possibly, as it did in Poland, manifest itself in the form of Constitutional Court challenging many of EU acts that are not in conformity with Serbian laws. Nonetheless, at this point it would be too much to suggest that Serbia should reform its Constitution towards a broad acceptance of the principle of supremacy of EU law. The solution should, as always, be found somewhere in the middle. Namely, it could be considered that constitutional review should be arranged in the same way the legislative competences between the EU and member states is done. In the area of exclusive competences, where the legislature has no competences in passing laws anymore, the principle of supremacy of EU law should completely be accepted. Following this line of argument, the Constitutional Court should be stripped of its powers to interpret EU law and to decide upon its validity in this field. As far as shared competences are concerned, the national legislature operates only if the EU decides not to practice its powers in the given area, or if it decides to task the national legislature with the power to regulate the given area. Serbia ought to invest in applying a form of the approach guided by the constitutional pluralism doctrine, which grants EU law a special status, but within a framework of fundamental principles set forth by the Constitution, such as fundamental rights, rule of law, separation of powers, etc. This would mean that the Constitutional Court would conduct the ultra vires control of activities of EU institutions, i.e. check whether they are acting within their legally established lines of competence. Through such a function, the Constitutional Court should perform the task of safeguarding the principles that represents the core of the national constitutional system (Chalmers, Davies, Monti, 2009, p. 197).

\section{Conclusion}

Serbia has already pledged to adapt its Constitution in accordance with the requirements laid down in the accession process. However, the set of planned reforms is not going to be sufficient. Serbia is not only going to have to tackle the issues of safeguarding the independence and 
impartiality of its judiciary and the prosecution, but it will also have to address some key constitutional issues, even those that are at the heart of a country's constitutional identity, such as the transfer of sovereign rights, supremacy and direct effect of EU law, limiting the competences of the Constitutional Court on some matter, etc. Since on many of these issues there are no hard conditions set out, nor strict rules that acceding countries have to abide by, Serbia can easily pick and choose with elements to implement and which to ignore. However, Serbia should also keep in mind that, through acceding to the Union, it is also entering a completely different international legal regime, which sits on its own rules.Conducting a wholesome change to the constitutional system could be beneficial, as it would eliminate many of the problems that could occur in cases of emergence of conflict between two legal systems jurisdictions.

\section{References}

Antonijević, M. et al (2013). Ustav Republike Srbije- sedam godina pravne neizvesnosti $i$ pet prioriteta za promenu. Beograd: YUCOM (Lawyers' Committee for Human Rights).

Arnold, R. (2016). Limitation of Sovereignty by European Integration: The German Experience in a Comparative View. Limitations of National Sovereignty through European Integration, IusGentium: Comparative Perspectives on Law and Justice, 1-13.

Borchardt, K. (2010). The ABC of European Union law. Luxembourg: Publications Office of the European Union.

Čavoški, A. (2013). Odnosprava EU i nacionalnog prava- značaj načela suprematije. Basic Concepts of Public International Law: Monism and Dualism, Institute for International Politics and Economic, Belgrade, 8595.Chalmers, D., Davies, G. T., \& Monti, G. (2010). European Union law: Cases and materials. Cambridge, UK: Cambridge University Press.

Crnić, M. (2015). The European Union- Western Balkans Relations.Studia Juridica et Politica Jaurinensis, 1, 12-22.

Miščević, T. (2009). Pridruživanje Evropskoj uniji. Beograd: Službeni glasnik.

Petrović, V., Stojanović, S., and Turkalj, K., Vodič kroz Izveštaj o skriningu za Poglavlje 23- Pravosude i osnovnaprava. Beograd: GIZ.

Vorpsi, A. (2016). The Europeanization of Albanian Constitutional Law. Limitations of National Sovereignty through European Integration, IusGentium: Comparative Perspectives on Law and Justice, 166-167. 


\section{Documents:}

- Communication from the Commission to the European Parliament, the Council, the European Economic and Social Committee and the Committee of the Region. EU Enlargement Strategy. Brussels, 10.11.2015.

- European Commission. Country Report for Serbia 2015.

- European Commission for Democracy through Law (Venice Commission). Opinion on the Constitution of Serbia. March 2007.

- European Commission. Screening Report Serbia: Chapter 24- Justice, Freedom and Security.

- Ministry of Justice of Serbia. Action Plan for Chapter 23.

\section{Legal acts:}

- Charter of Fundamental Rights of the European Union

- Constitution of Croatia

- Constitution of Serbia

- Treaty on the European Union

- Treaty on the Functioning of the European Union

\section{Case Law:}

- Judgment of the Court of 17 December 1970. - Internationale Handelsgesellschaft mbH $v$ Einfuhr- und Vorratsstelle für Getreide und Futtermittel. - Reference for a preliminary ruling: Verwaltungsgericht Frankfurt am Main - Germany. - Case 11-70.

-Judgment of theCourtof9March1978.-AmministrazionedelleFinanzedelloStato $v$ SimmenthalSpA. - Reference for a preliminary ruling: Pretura di Susa Italy. - Discarding by the national court of a law contrary to Community law. - Case 106/77.

- Judgment of the Court of 23 April 1986, Parti Ecologiste "Les Verts" v. European Parliament, Case 294/83 